\title{
Cross shelf gradients of scleractinian corals in the Spermonde Islands, South Sulawesi, Indonesia
}

\author{
SYAFYUDIN YUSUF ${ }^{1}$, MARIA BEGER ${ }^{2}$, ASMI CITRA MALINA A.R. TASSAKKA ${ }^{1}$, \\ MAARTEN DE BRAUWER ${ }^{2}$, AMANDA PRICELLA ${ }^{3}$, RAHMI $^{4}$, WIDYASTUTI UMAR ${ }^{1,3}$, GINO V. LIMMON $^{5}$, \\ ABIGAIL MARY MOORE ${ }^{3}$,JAMALUDDIN JOMPA ${ }^{1,3, \varphi}$ \\ ${ }^{1}$ Faculty of Marine Science and Fisheries, Universitas Hasanuddin. J1. Perintis Kemerdekaan Km. 10, Tamalanrea, Makassar 90245, South Sulawesi, \\ Indonesia. Tel./fax.: +62-411-586025, ^email: j.jompa@unhas.ac.id \\ ${ }^{2}$ University of Leeds. Woodhouse, Leeds LS2 9JT, United Kingdom \\ ${ }^{3}$ Graduate School, Universitas Hasanuddin. Jl. Perintis Kemerdekaan Km. 10, Tamalanrea, Makassar 90245, South Sulawesi, Indonesia \\ ${ }^{4}$ Universitas Muhammadiyah Makassar. Jl. Sultan Alauddin 259, Rappocini, Makassar 90221, South Sulawesi, Indonesia \\ ${ }^{5}$ Universitas Pattimura. Jl. Ir. M. Putuhena, Poka, Ambon 97233, Maluku, Indonesia
}

Manuscript received: 8 December 2020. Revision accepted: 21 February 2021

\begin{abstract}
Yusuf S, Beger M, Tassakka ACMAR, Brauwer MD, Pricella A, Rahmi, Umar W, Limmon GV, Moore AM, Jompa J. 2021. Cross shelf gradients of scleractinian corals in the Spermonde Islands, South Sulawesi, Indonesia. Biodiversitas 22: 1415-1423. Coral reef ecosystems around the world have suffered extensive degradation, including the reefs of the Wallacea region within the Coral Triangle global biodiversity hotspot. Anthropogenic and natural threats can reduce the level of coral reef biodiversity differentially across environmental or impact gradients. The purpose of this study was to evaluate the changes in hard coral (Scleractinia) diversity and community structure across an inshore-offshore zonation gradient in the Spermonde Islands, South Sulawesi, Indonesia. Data on coral colony species and abundance as well as live coral cover were collected from $10 \mathrm{~m}^{2}$ belt transects at a depth of 6 to $8 \mathrm{~m}$. A total of 72 transects were placed around the 12 island stations in three zones: the inner mid-shelf zone, outer mid-shelf zone and outer shelf zone. Data were analyzed to determine the species richness, and three ecological indices for the hard coral communities were calculated: the Shannon Diversity Index (H'), Similarity Index (E), and Dominance Index (C). A total of 310 hard coral species belonging to 62 genera were recorded. The coral communities were dominated by the genera Fungia, Montipora and Porites, and coral cover was in the 'moderate' category. The number of species was directly proportional to the number of colonies within each zone. Live coral cover was higher in the inner mid-shelf zone and outer shelf zone than the outer mid-shelf zone; conversely, the species richness and coral colony abundance were higher in the outer mid-shelf zone. However, the differences were not statistically significant. The indices H', C, and E did not differ significantly between the zones. However, Tambakulu Island in Zone 4 had the lowest values of $\mathrm{E}$ and $\mathrm{H}^{\prime}$ and the highest value of $\mathrm{C}$. Findings suggest that most-hard coral communities in the cross-shelf zones of the Spermonde Islands are stable communities characterized by relatively high diversity and low dominance indices.
\end{abstract}

Keywords: Biodiversity, Coral Triangle, ecological indices, Scleractinia, Wallacea Region

\section{INTRODUCTION}

Reef building or stony corals (Scleractinia) are widely distributed throughout the tropical and subtropical regions of the world (Obura 2012). Distribution patterns can be expressed in terms of the numbers of taxa (e.g. genera or sub-generic groups) present in different regions (Wallace et al. 1991). Coral reef ecosystems are a key storehouse of marine biodiversity (Kondo and Hashimoto 2010; Hoeghguldberg et al. 2018). Wallacea is a terrestrial and marine megadiversity area in the western Indo-Pacific, comprising the region between the Wallace Line which extends from the Philippines through the Makassar Strait to the Lombok Strait to the west and the Lydekker Line to the east (Lohman et al. 2011). The Wallacea Line divides the western (Sunda Shelf) from the eastern Indonesian biodiversity areas. Alfred Wallace concentrated much of his study on the biodiversity of eastern Indonesia, in particular the islands of Sulawesi, Maluku, Halmahera, Nusa Tenggara and the seas around them, undertaking a major voyage of exploration lasting from 1854 to 1862
(Lloyd et al. 2010). Since then there has been considerable amount of research on coral biodiversity in the coral reef ecosystems of Southeast Asia in general, and Wallacea in particular (Moll 1983; Best et al. 1989; Hoeksema 2012a, 2012b; Veron et al. 2015). Geographical variations within the Southeast Asia region affect the level of biodiversity, as reflected in the delineation of the Coral Triangle (Veron et al. 2009), the global epicenter of coral reef biodiversity (Barber et al. 2011), with at least 627 species of coral and many finer-scale ecoregions (Veron et al. 2015).

In addition to their intrinsic biodiversity value, coral reef ecosystems support the livelihoods of millions of people, including through locally and globally important fisheries (Cullen 2010; Burke et al. 2012; Hughes et al. 2014; Rhyne et al. 2014; Cabral and Geronimo 2018), However, as for coral reefs worldwide (Hughes et al. 2014; Weijerman et al. 2018), the coral reef ecosystems in the Wallacea region are not free from anthropogenic disturbances which can reduce the level of biodiversity and ecosystem services (Green et al. 2014). These include destructive fishing, overfishing, land-based and marine 
pollution, the effects of land-use changes such as run-off, eutrophication and sedimentation, coastal development, anthropogenic climate change and ocean acidification (Burke et al. 2012; Ambo-Rappe and Moore 2018; Heery et al. 2018). Collectively, these stressors are severely degrading the reef ecosystems, threatening sustainable fisheries, tourism, coastal protection, and a myriad of other ecosystem services provided by reefs, in some cases causing irreversible changes to community structure and productivity (Green et al. 2014; Hughes et al. 2014; Hoey et al. 2016). While efforts have been made to reduce some of the more obvious direct impacts such as destructive fishing, the revised regional autonomy law UU 23/2014 has resulted in (hopefully temporary) setbacks (Ambo-Rappe and Moore 2018), and over-fishing remains a pervasive problem (Burke et al. 2012; Ferse et al. 2012; Ferse et al. 2014; Glaser et al. 2018).

Many reefs in the Wallacea region appear to have escaped historical thermal stress and large-scale environmental disturbances. Such reefs are seen as being global importance as potential refugia (Weijerman et al. 2018). Nonetheless, like all tropical coral reef ecosystems, it is predicted that these reefs are or will eventually be imperiled due to predicted climate trends and associated impacts (Burke et al. 2012). Indeed, there are signs that, despite the apparent relatively high resistance or resilience of some reefs to past and current levels of local and climate-related stressors (Heery et al. 2018; Williams et al. 2019), they are also likely to be increasingly vulnerable as global warming accelerates (Oliver et al. 2019; AndradiBrown et al. 2020). For example, areas that did not bleach in the 1998 or 2010 global coral bleaching events did bleach in 2016 (Moore et al. 2017; Ambo-Rappe and Moore 2018; Moore et al. 2019). Furthermore, bleaching patterns may not always be visible; while shallow reefs typically bleached most in 2010 (Muslihuddin et al. 2012; Yusuf and Jompa 2012), in 2016 bleaching was only observed at depths below $7 \mathrm{~m}$ in the Spermonde (Yusuf, unpublished data) and Menui (Ambo-Rappe and Moore 2018) Archipelagos.

Understanding the complex interactions and dynamic responses of coral reef communities to multiple stressors is key to predicting future trends and managing reefs to sustain ecosystem services (Edinger et al. 1998; Hughes et al. 2014; Weijerman et al. 2018; Andradi-Brown et al. 2020). The coral reef ecosystem in the Spermonde Islands, South Sulawesi, offers an example where coral reef ecosystem disruption comes from anthropogenic activities in the sea and land, with an inshore-offshore gradient (Edinger et al. 1998; Hoeksema 2012a; Plass-Johnson et al. 2018a). The Fungiidae are one coral taxon exhibiting ecological differentiation in distribution patterns along cross-shelf environmental gradients in the area (Hoeksema 2012b).

There have been studies on various aspects of reef health and biodiversity across this gradient in the Spermonde Islands over the past decades (Moll 1983; Best et al. 1989; CRITC 2012; Hoeksema 2012b), as well as more recent studies on coral reefs and associated biodiversity (Plass-Johnson et al. 2018a; Plass-Johnson et al. 2018b; Teichberg et al. 2018). However, there is a need for updated and/or complementary data on certain aspects of coral community biodiversity, ecology and health. Molecular biology methods are gaining in popularity for a wide range of biodiversity-related studies in the marine realm (Bourlat et al. 2013; Bowen et al. 2014; von der Heyden et al. 2014; Crandall et al. 2019) including for corals (Gittenberger et al. 2011; Umar et al. 2019; Jompa et al. 2020). In particular, environmental DNA (eDNA) can provide data on the taxonomic groups present (Berry et al. 2019), and in some cases also provide an indication of relative abundance (Kutti et al. 2020). However, there is still a need for ground-truthing, particularly with respect to the abundance of taxonomic groups such as the Scleractinia where eDNA has not been widely used.

This research aimed to estimate the species and genus level biodiversity and abundance of coral colonies and evaluate the interactions between anthropogenic pressures and coral community characteristics across an inshoreoffshore gradient using standard ecological indices. An additional objective of the study was to provide data which could be used to evaluate the results of a parallel study on coral community biodiversity using a molecular biology method (eDNA) with respect to both species identified and their relative abundance. The fine-scale taxonomic data generated by this study will contribute to the knowledge on coral biodiversity and biogeography, while the existence of historical (time series) data should make the ecological data particularly valuable to both managers and researchers.

\section{MATERIALS AND METHODS}

\section{Research site - overview of the Spermonde Islands}

The Spermonde Islands lies off the southwestern coast of Sulawesi island (Indonesia) on a wide but shallow coastal shelf. Starting from the city of Makassar on the Sulawesi mainland, the shelf extends around $40 \mathrm{~km}$ west into the Makassar strait (Hoeksema 2012b). Around 80 small islands formed from coral sand (coral cays) are bathed by the Indonesian Throughflow (ITF) in the Makassar Strait. Due to the currents, scleractinian corals naturally grow well, forming fringing reefs and patch reefs with barrier reefs along the outer margin of the shelf.

Four zones have been delineated in the Spermonde Islands, representing an onshore-offshore gradient in both ecological conditions and anthropogenic pressures (Hoeksema 2012b). The innermost zone (Zone 1) runs parallel to the shore, and is delimited by the $20 \mathrm{~m}$ isobath; all potentially habitable islands in this zone are inhabited, often at very high densities. The second zone or inner midshelf zone (Zone 2) begins around 5 to $12.5 \mathrm{~km}$ from shore with a maximum depth of around $30 \mathrm{~m}$. Most islands are inhabited, with many coral-covered patch reefs below the surface of the shallow waters. The third zone, around 12.5 to $30 \mathrm{~km}$ offshore, is the outer mid-shelf zone (Zone 3 ) which is influenced to some extent by offshore (oceanic) waters, with depths reaching 30 or $50 \mathrm{~m}$. Corals are generally found growing on submarine shoals with no islands, or uninhabited sandy cays. The outermost reefs in 
the fourth (outer shelf) zone (Zone 4) form extensive but discontinuous barrier reefs around $30-40 \mathrm{~km}$ from land and are directly exposed to offshore conditions. Several islands along the barrier reef are inhabited, such as Langkai, Lanjukang, and the islands in the Kapoposang Marine Tourism Park (Kapoposang, Papandangan, Gondong Bali, and Suranti). Depths in this zone tend to be around 40 to 50 $\mathrm{m}$, while at the outer edge of the shelf on which the Spermonde Islands is sited, the seafloor plunges steeply to depths of 100 to $200 \mathrm{~m}$.

\section{Sampling time and sites}

The field survey took place in May 2019. The sampling sites comprised 12 islands, with four islands representing each of three cross-shelf zones in the Spermonde Islands (Figure 1). In Zone 2 (inner mid-shelf zone) these were: Barrang Lompo, Sanane, Polewali, and Ballang Lompo; in Zone 3 (outer mid-shelf zone): Bone Tambu, Lumu Lumu, Sarappo Lompo, and Samatellu Lompo; and in Zone 4 (outer zone): Lanjukang, Langkai, Tambakulu, Kapoposang.

\section{Coral community data collection}

This study was carried out as part of a wider research program employing Environmental DNA (eDNA) methods to evaluate the biodiversity and structure of hard coral (Scleractinia) communities in the Indonesian Wallacea region. At each site (island), three $50 \mathrm{~m}$ line transects were laid at a depth of around 6 to $8 \mathrm{~m}$. Along each line transect, data were collected within two belt transects (each $10 \mathrm{~m} \mathrm{x}$ $\left.1 \mathrm{~m}=10 \mathrm{~m}^{2}\right)$ along the $50 \mathrm{~m}$ line transect $(0-10 \mathrm{~m}$ and $30-40$ $\mathrm{m})$, giving a total survey area of $60 \mathrm{~m}^{2}$ per site, $240 \mathrm{~m}^{2}$ per zone and $720 \mathrm{~m}^{2}$ overall. Coral reef condition was evaluated based on percentage hard coral cover $(\% \mathrm{HC})$ using the standard established by the Indonesian Ministry of the Environment in Decree KEP - 04/MENLH/02/2001: Poor (0-24.9\%); Moderate (25-49.9\%); Good (50-74.9\%); and Excellent (75-100\%) (Kementerian Lingkungan Hidup 2001). All coral colonies within each transect were counted and identified to species level, or where this was not possible to genus level. Identification was conducted in the field and in the laboratory-based on photographs taken in the field and/or specimens. Samples of specimens that could not be identified in the field were collected, bleached and dried in the field and identified in the Coral Centre Laboratory of Hasanuddin University. The identification process was based on references (Wallace 1999; Veron 2000).
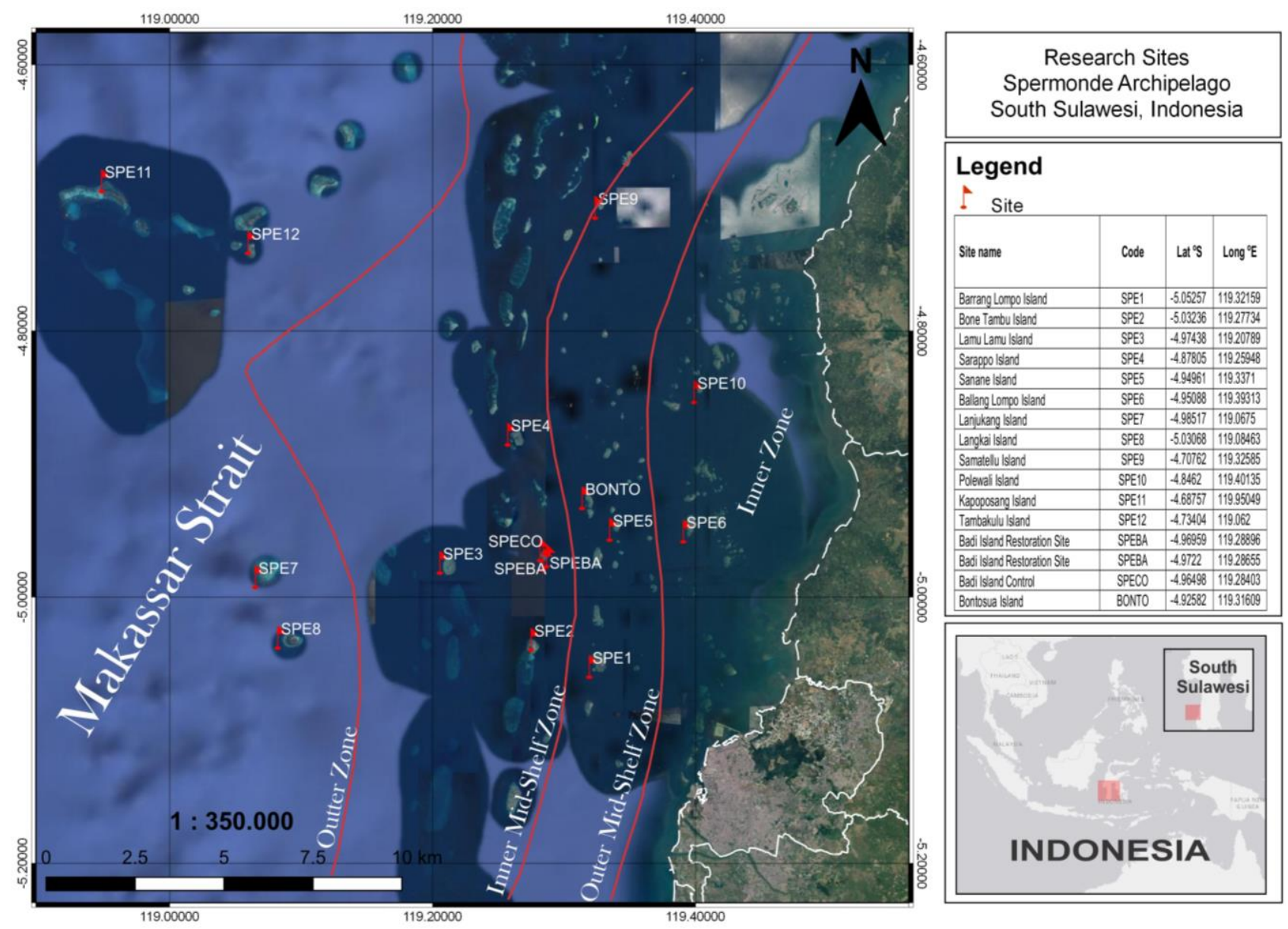

Figure 1. Cross-shelf zones and study sites in the Spermonde Islands, South Sulawesi, Indonesia 


\section{Data analysis}

Data were tabulated in Microsoft Excel 2010 and analyzed descriptively. All statistical analyses were performed, and graphics were produced in Excel 2010. Three ecological indices were calculated: the ShannonWeiner Diversity Index (H'), the Index of Dominance (C), and Evenness Index (E), following Morris et al. (2014). The indices were evaluated as follows based on Krebs (1999): (i) Diversity Index: low diversity $H^{\prime} \leq 2$; moderate diversity $2<\mathrm{H}^{\prime} \leq 3$; and high diversity $\mathrm{H}^{\prime}>3$; (ii) Dominance Index: low dominance $0<\mathrm{C} \leq 0.5$; moderate dominance $0.5<\mathrm{C} \leq 0.75$; and high dominance $0.75<\mathrm{C} \leq$ 1; (iii) Evenness Index: community under pressure: $0<\mathrm{E} \leq$ 0.5 ; unstable community $0.5<\mathrm{E} \leq 0.75$; stable community $0.75<\mathrm{E} \leq 1$. The statistical significance of between zone differences in the mean values of the parameters calculated was evaluated using the analysis of variance (ANOVA) routine at the $95 \%$ confidence limit $(\alpha=0.05)$. The correlation between coral abundance (colony count) and diversity (species count) was evaluated through a linear regression of $\log _{10}$ transformed data.

\section{RESULTS AND DISCUSSION}

\section{Scleractinian coral biodiversity, condition and density}

From the total area of $720 \mathrm{~m}^{2}$ studied using the belt transect method, 3079 coral colonies representing 310 species and 62 genera of scleractinian corals were recorded from the reefs around 12 islands in the Spermonde Islands (Table 1). Based on the mean \% HC cover, the mean condition of the reefs in each zone and that of all sites in Zone 4 was in the moderate category, while in Zones 2 and 3 reef condition was more varied, ranging from poor to good. None of the reefs studied were in the excellent condition category.

The overall means species richness and colony abundance per site were 101 species and 575 colonies per $60 \mathrm{~m}^{2}$, equivalent to a coral colony density of $9.6 \cdot \mathrm{m}^{-2}$. The mean coral colony count and mean species countfor each zone are shown in Figure 2.
The mean coral colony density in Zone 3, the outer mid-shelf zone, was 121 colonies per $10 \mathrm{~m}^{2}$, considerably higher but not significantly $(p>0.05)$ different from the mean densities in Zone 2 (inner mid-shelf) and Zone 4 (outer zone), both of which averaged 87 colonies per $10 \mathrm{~m}^{2}$ (Figure 3).

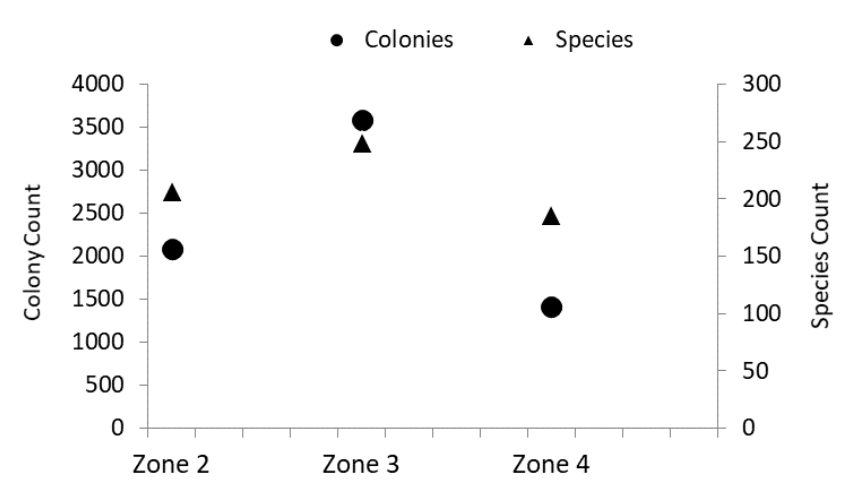

Figure 2. Coral species count and colony count by cross-shelf zone in the Spermonde Islands, South Sulawesi, Indonesia

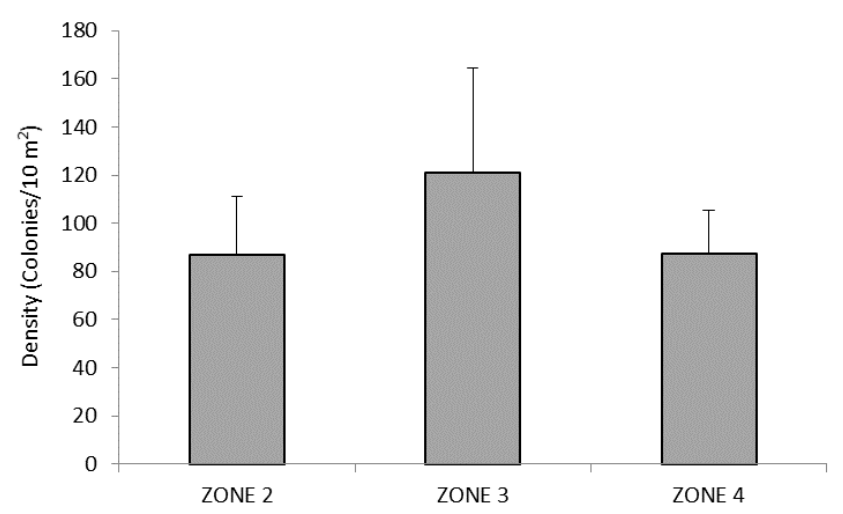

Figure 3. Coral colony density by zone in the Spermonde Islands, South Sulawesi, Indonesia (bars: mean; whiskers: standard deviation)

Table 1. Number of scleractinian coral colonies, number of species and hard coral cover $(\% \mathrm{HC})$ by zone $\left(240 \mathrm{~m}^{2}\right)$ and island $\left(60 \mathrm{~m}^{2}\right)$ in the Spermonde Islands, South Sulawesi, Indonesia (belt transect data, total area surveyed $720 \mathrm{~m}^{2}$ )

\begin{tabular}{cclccc}
\hline Zone & Mean HC $(\boldsymbol{\%})$ & \multicolumn{1}{c}{ Site (island) } & Colonies & Species & Mean HC $(\boldsymbol{\%})$ \\
\hline Zone 2 & \multirow{2}{*}{33.5} & Sanane & 705 & 122 & 50.07 \\
& & Barrang Lompo & 432 & 109 & 41.25 \\
& & Ballang Lompo & 570 & 102 & 17.23 \\
Zone 3 & Polewali & 377 & 88 & 25.56 \\
& & Bone Tambu & 347 & 132 & 8.04 \\
& \multirow{3}{*}{32.1} & Sarappo Lompo & 703 & 118 & 35.36 \\
Zone 4 & & Samatellu Lompo & 577 & 111 & 32.84 \\
& & Lumu Lumu & 1089 & 94 & 52.21 \\
& & Lanjukang & 517 & 103 & 38.08 \\
& \multirow{3}{*}{33.4} & Kapoposang & 448 & 96 & 31.26 \\
& & Langkai & 457 & 94 & 26.00 \\
\end{tabular}




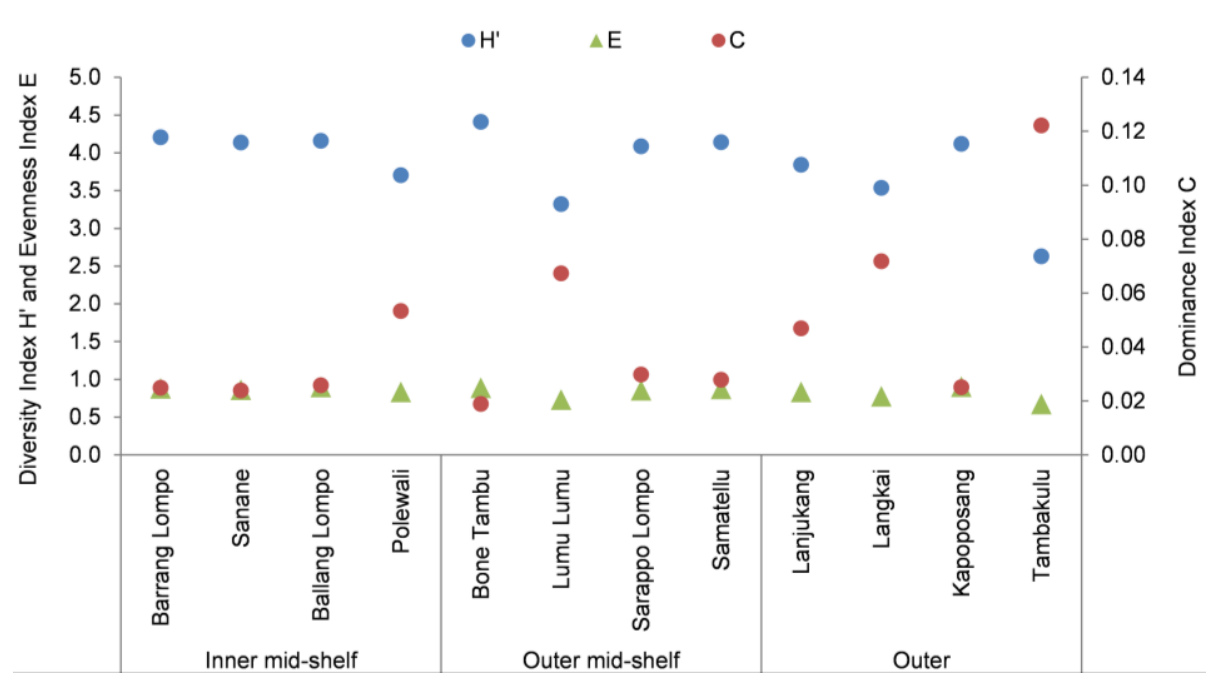

Figure 4. Ecological indices of scleractinian coral communities around 12 islands in the Spermonde Islands, South Sulawesi, Indonesia

\section{Scleractinian coral community ecological indices}

The three ecological indices calculated for the coral communities were similar for most of the 12 sites in three cross-shelf zones (Figure 4). One site (Tambakulu Island in Zone 4) differed noticeably from the overall pattern of the other 10 sites, with the lowest Diversity Index H' value and the highest value for the Dominance Index $\mathrm{C}$. This site was also the only site with an $\mathrm{E}$ value less than 0.75 , indicating an unstable community, despite having above average coral cover $(38.22 \%)$.

\section{Correlation between scleractinian coral diversity and abundance}

The three genera with the highest abundance were Fungia, Montipora and Porites, accounting for nearly half (48.64\%) of all colonies and $20.00 \%$ of all species recorded (Table 2). The genus Porites accounted for $17.93 \%$ of colonies and $5.81 \%$ of species; Fungia for $16.78 \%$ of colonies and $9.03 \%$ of species; and Montipora for $13.94 \%$ of colonies and $5.16 \%$ of species.

The linear regression of the $\log _{10}$-transformed data (Figure 5) showed a moderately strong positive correlation $(\mathrm{R} 2 \approx 0.6)$ between the number of species within a genus and the colony count for that genus. The $\mathrm{R}^{2}$ value indicates that, for a given genus, around $77 \%$ of the variation in colony count can be explained by the number of congeneric species present.

\section{Discussion}

\section{Coral biodiversity and abundance}

The number of coral species identified in this study is greater than that in previous studies. For example, Moll (1983) found 262 species belonging to 69 genera, less than the current study; these figures were also presented in Best et al. (1989). However, Moll (1983) did not cover all the sites in our study, for example, Kapoposang was not included. Conversely, Moll (1983) studied islands in Zone $\mathrm{I}$, at a time when environmental conditions in this zone were still relatively good. Nowadays, the degradation due to coastal development has greatly reduced both coral cover and coral diversity in Zone 1 (Heery et al. 2018), which was not included in our study.

A recent evaluation of coral reef management in Indonesia (Susanto et al. 2015) quoted the same figure, but attributed the 262 species to Kapoposang, which was not covered by Moll (1983); this could be a case of spatial confusion or due to a lack of additional species identified in that area. The Spermonde Islands has split administratively between Pangkajene Kepulauan (Pangkep) District to the north and Makassar City to the south, both within South Sulawesi Province. A survey in 2010 which was limited to reefs under the jurisdiction of Makassar City identified 191 scleractinian coral species (S. Yusuf, unpublished data 2010), while surveys in the Pangkep area in 2012 (CRITC 2012) found just 110 species. It should be noted that, while all other surveys used belt transect methods, the survey conducted by the Indonesian Institute for Science (LIPI) in 2012 used a line intercept transect (LIT) method, a factor that could account for the lower species count.

With respect to the zones, the species richness did not follow the expected pattern of inshore-offshore cross-shelf increase from Zone 2 to Zone 4 . Despite the terrestrial influences apparent in Zone 2, including eutrophication due to the pollution of the rivers flowing into the sea, the lowest overall species richness was observed in Zone 4 (186 species), with the highest coral diversity in Zone 3 (249 species), followed by Zone 2 (207 species). The pattern of colony abundance was similar to that of species richness, as seen in Table 1 and Figure 2.

At a site (island) level, three of the five sites with the highest species richness were in Zone 3, with Lumu Lumu Island being the one exception. Only one site in Zone 4 (ranked $6^{\text {th }}$ ) had more than 100 species (Lanjukang Island), while the site with the lowest species count was Tambakulu Island in Zone 4, in the outer reaches of the Archipelago. However, it should be noted that, at each site (island), data were collected from a limited sample of the reef ecosystem. In addition to the limited total area $\left(60 \mathrm{~m}^{2} / \mathrm{site}\right)$, data were only collected at a single depth, 6 to $8 \mathrm{~m}$. It is possible that the depth at which maximum scleractinian diversity occurs may differ between sites. 
Table 2. Total frequency of occurrence (number and $\%$ of colonies observed), the number and $\%$ of species within each coral genus observed in the Spermonde Islands during this research

\begin{tabular}{|c|c|c|c|c|c|c|c|c|c|}
\hline \multirow{2}{*}{ Genus } & \multicolumn{2}{|c|}{ Colonies } & \multicolumn{2}{|c|}{ Species } & \multirow{2}{*}{ Genus } & \multicolumn{2}{|c|}{ Colonies } & \multicolumn{2}{|c|}{ Species } \\
\hline & $\mathbf{n}$ & $\%$ & $\mathbf{n}$ & $\%$ & & $\mathbf{n}$ & $\%$ & $\mathbf{n}$ & $\%$ \\
\hline Fungia & 1262 & 17.93 & 18 & 5.81 & Pachyseris & 37 & 0.53 & 3 & 0.97 \\
\hline Montipora & 1181 & 16.78 & 28 & 9.03 & Sandalolitha & 33 & 0.47 & 2 & 0.65 \\
\hline Porites & 981 & 13.94 & 16 & 5.16 & Goniopora & 26 & 0.37 & 6 & 1.94 \\
\hline Acropora & 319 & 4.53 & 40 & 12.90 & Echinophyllia & 24 & 0.34 & 4 & 1.29 \\
\hline Seriatopora & 260 & 3.69 & 3 & 0.97 & Mycedium & 24 & 0.34 & 4 & 1.29 \\
\hline Galaxea & 252 & 3.58 & 2 & 0.65 & Halomitra & 23 & 0.33 & 2 & 0.65 \\
\hline Echinopora & 225 & 3.20 & 6 & 1.94 & Coscinaraea & 22 & 0.31 & 2 & 0.65 \\
\hline Goniastrea & 213 & 3.03 & 10 & 3.23 & Coeloseris & 20 & 0.28 & 1 & 0.32 \\
\hline Pavona & 178 & 2.53 & 10 & 3.23 & Isopora & 19 & 0.27 & 1 & 0.32 \\
\hline Cyphastrea & 168 & 2.39 & 6 & 1.94 & Plesiastrea & 19 & 0.27 & 1 & 0.32 \\
\hline Millepora & 167 & 2.37 & 3 & 0.97 & Leptoria & 18 & 0.26 & 1 & 0.32 \\
\hline Ctenactis & 147 & 2.09 & 3 & 0.97 & Stylocoeniella & 17 & 0.24 & 1 & 0.32 \\
\hline Favites & 131 & 1.86 & 10 & 3.23 & Turbinaria & 14 & 0.20 & 5 & 1.61 \\
\hline Astreopora & 118 & 1.68 & 8 & 2.58 & Caulastrea & 13 & 0.18 & 2 & 0.65 \\
\hline Leptastrea & 100 & 1.42 & 6 & 1.94 & Oulophyllia & 12 & 0.17 & 1 & 0.32 \\
\hline Montastrea & 94 & 1.34 & 9 & 2.90 & Polyphillia & 12 & 0.17 & 1 & 0.32 \\
\hline Platygyra & 87 & 1.24 & 7 & 2.26 & Herpolitha & 11 & 0.16 & 1 & 0.32 \\
\hline Favia & 84 & 1.19 & 14 & 4.52 & Diploastrea & 10 & 0.14 & 1 & 0.32 \\
\hline Merulina & 82 & 1.16 & 2 & 0.65 & Cycloseris & 9 & 0.13 & 3 & 0.97 \\
\hline Leptoseris & 78 & 1.11 & 11 & 3.55 & Acanthastrea & 8 & 0.11 & 5 & 1.61 \\
\hline Pectinia & 56 & 0.80 & 5 & 1.61 & Tubastrea & 8 & 0.11 & 2 & 0.65 \\
\hline Hydnopora & 53 & 0.75 & 3 & 0.97 & Heliofungia & 7 & 0.10 & 1 & 0.32 \\
\hline Pocillopora & 50 & 0.71 & 3 & 0.97 & Physogyra & 7 & 0.10 & 1 & 0.32 \\
\hline Psammocora & 50 & 0.71 & 7 & 2.26 & Plerogyra & 5 & 0.07 & 1 & 0.32 \\
\hline Stylophora & 48 & 0.68 & 2 & 0.65 & Australogyra & 4 & 0.06 & 1 & 0.32 \\
\hline Podabacia & 41 & 0.58 & 2 & 0.65 & Heliopora & 4 & 0.06 & 1 & 0.32 \\
\hline Symphyllia & 41 & 0.58 & 4 & 1.29 & Lithophyllon & 4 & 0.06 & 2 & 0.65 \\
\hline Euphyllia & 39 & 0.55 & 2 & 0.65 & Scolymia & 4 & 0.06 & 2 & 0.65 \\
\hline Oxypora & 39 & 0.55 & 3 & 0.97 & Tubipora & 4 & 0.06 & 1 & 0.32 \\
\hline Barabattoia & 37 & 0.53 & 2 & 0.65 & Gardineroseris & 2 & 0.03 & 1 & 0.32 \\
\hline Lobophyllia & 37 & 0.53 & 4 & 1.29 & Alveopora & 1 & 0.01 & 1 & 0.32 \\
\hline
\end{tabular}

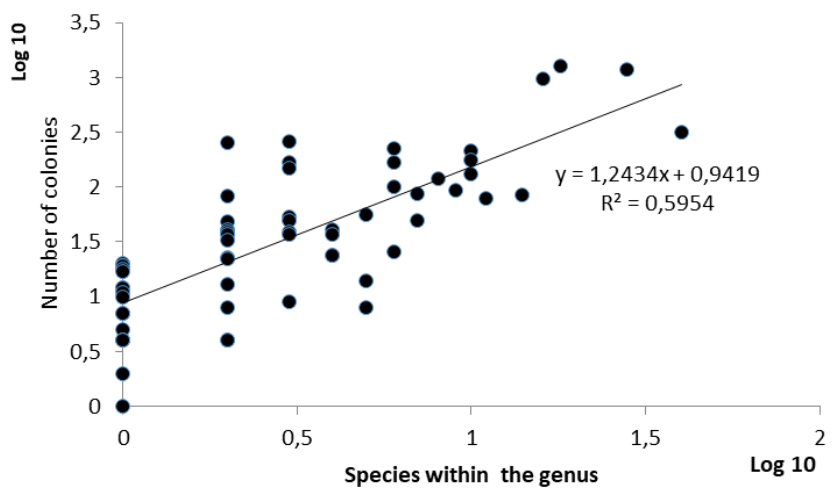

Figure 5. $\log _{10}$ transformed linear regression relationship between species richness and total number of coral colonies for each scleractinian coral genus recorded around 12 islands in 3 zones of the Spermonde Islands, South Sulawesi, Indonesia

At most sites, coral colony density was highest in shallow waters and decreased with increasing depth. This was especially noticeably for the genus Acropora, the most speciose extant coral genus (Wallace et al. 2012). Only 319 acroporid colonies were counted from all 72 transects at 6 to8 $\mathrm{m}$ depth. During the survey, qualitative observations showed that Acropora colonies were more abundant and appeared denser on the shallower areas of the reef crest and/or the reef flat. Historical data, in particular old photographs show a naturally high abundance of acroporid corals in the Spermonde Islands, and this genus was still the most abundant in 2006 (Yusuf and Jompa 2012). Therefore, it is possible that the diversity and abundance of this species were underestimated due to the survey methodology used. It is also possible that acroporid abundance was low due to direct and indirect human impacts, and that a combination of factors contributed to the relatively low abundance of the genus Acropora in this study. This taxon is relatively vulnerable to both mechanical damage and climate impacts, especially coral bleaching (Yusuf and Jompa 2012; Decarlo et al. 2017). Furthermore, corals of the genus Acropora are reputed to prefer high light intensity; their depth distribution tends to be related to and limited by light penetration (Yentsch et al. 2002), and hence water quality (Strahl et al. 2019). Coral planula settlement rates tend to be higher at higher light intensities (Yusuf et al. 2019), and juvenile Acropora colonies are particularly sensitive to suspended particles and sedimentation, irrespective of light intensity as well as 
excessively attenuated light penetration (Humanes et al. 2017; Moeller et al. 2017). Acroporid corals are also favored by Acanthaster planci, the corallivorous crown of thorns starfish (Wallace et al. 2012). A severe A. planci outbreak occurred in the Spermonde Islands in 2012-2013 (Plass-Johnson et al. 2015), resulting in high levels of coral mortality (in some cases more than 50\%). Visual records from this outbreak show high levels of $A$. planci predation on Acropora, in particular tabulate colonies (Plass-Johnson et al. 2015).

Coral genera with very low abundance at the survey depth (6 to $8 \mathrm{~m}$ ) were Plerogyra, Heliopora, Australogyra, Scolymia, Tubipora, Gardineroseris and Alveopora. These corals are generally considered relatively rare; they are also noted for their limited reproductive and dispersal capacity. These factors might account for the low abundance observed, although natural scarcity may have been exacerbated by mortality due to anthropogenic factors coupled with low regenerative capacity.

\section{Scleractinian coral community characteristics and cross- shelf gradient}

Overall, the values of the ecological indices are typical of relatively stable and diverse communities, with low dominance at all sites. A higher Evenness Index (E) typically indicates more diverse and balanced communities, not dominated by a few species. The one site with an E value not in the stable category was Tambakulu Island (Zone 4); however, coral cover at this site was relatively high and the Diversity Index $\mathrm{H}^{\prime}$ was in the moderate category. The 2012 survey (CRITC 2012) reported $H^{\prime}$ values in the range of 1.73 to 3.06 , mostly in the moderate category, and $\mathrm{E}$ values in the range 0.65 to0.93. Our results show generally higher $H^{\prime}$ values (2.63 to 4.41) and similar E values (0.675 to 0.902). As for the overall species count, one reason for this difference could be the transect methods used, i.e. LIT (Line Intercept Transect) rather than the belt transects used in this study.

In contrast to previous studies in the Spermonde Islands, we did not find a clear cross-shelf progression in any scleractinian coral community characteristic measured. The increase in density and diversity across the mid-shelf zone (from Zone 2 to Zone 3) was not statistically significant and did not continue into the outer reef area (Zone 4). The reasons for this unexpected pattern are not clear. However, in addition to water quality, which could be expected to improve across the shelf, other factors affecting coral community development and resilience include the presence of adult colonies and larval recruitment (Sawall et al. 2013). Intuitively, the outer midshelf (Zone 3 ) could receive more coral propagules, being situated between Zone 3 and Zone 4. Meanwhile, it is possible that recruitment may be less effective in the outer zone, due to stronger currents and wave action, which could reduce the settlement of coral planulae, and reduce survival of recently settled juveniles, especially on poorly consolidated substrate. As mentioned above, depth may also play a role, as in the clearer offshore reefs certain taxa might be found at a deeper depth; conversely, taxa adapted to a higher light intensity might be found above the $6-8 \mathrm{~m}$ depth used in this study.

As mentioned above, one of the goals of this study was to provide benchmark or ground-truthing data for a survey using environmental DNA (eDNA) metabarcoding methods. In this context, it will be interesting to see whether or not the patterns observed in this study are mirrored in the metabarcoding results. In particular, whether species richness patterns between sites and zones are similar; whether relative abundances of sequences attributed to each operational taxonomic unit indicate a similar pattern of relative inter-species and inter-genus abundance; and whether there is a correlation between taxonomic diversity and abundance.

The results of our study on scleractinian coral communities in the Spermonde Islands can be considered surprising. Contrary to expectations, we did not find any significant difference between zones across an inshoreoffshore gradient in scleractinian coral colony abundance, coral species richness or the ecological indices calculated. Number of colonies per genus showed a moderate but significant correlation with the number of species present within each genus. Three genera dominated the coral communities in terms of abundance: Fungia, Montipora and Porites. Observed coral biodiversity was high compared to historical data from this area; however the relatively low abundance of once common acroporid branching corals can be considered an indicator of direct and indirect human impacts on these reefs. We conclude that the hard coral communities in the cross-shelf zones of the Spermonde Islands can be categorized as apparently relatively stable and resilient communities characterized by mostly high diversity and low dominance indices. However, wise management at the local level will be needed to maintain the diversity and ecosystem services of these valuable ecosystems, while their ultimate fate will depend on the success of global efforts at all levels to mitigate climate change. These data provide a snapshot that can be used to compare with present and future studies on the coral communities of this region.

\section{ACKNOWLEDGEMENTS}

The authors wish to thank the Ministry for Research and Technology for funding under Grant No. 7/AMD/E1/KP.PTNBH/2020. Thanks are also due to all who participated in the fieldwork, especially Halwi.

\section{REFERENCES}

Ambo-Rappe R, Moore AM. 2018. Sulawesi Seas, Indonesia. In: Sheppard C (eds.). World Seas: An Environmental Evaluation, Volume II: The Indian Ocean to the Pacific, 2 ${ }^{\text {nd }}$ ed. Elsevier Academic Press, London, United Kingdom.

Andradi-Brown DA, Banaszak AT, Frazer TK, Gilchrist H, Harborne AR, Head CEI, Heather J. Koldewey HJ, Levy E, Richards K, Short R, Sweet M, Teleki K, Voolstra CR, Wilson B, Wood E, Yarlett RT, Curnick DJ. 2020. Coral reefs in the anthropocene - Reflecting on 20 years of reef conservation UK. Front Mar Sci 7: 00364. DOI: 10.3389/fmars.2020.00364. 
Barber PH, Cheng SH, Erdmann MV, Tenggardjaja K. 2011. Evolution and conservation of marine biodiversity in the Coral Triangle: Insights from stomatopod Crustacea. In: Held C, Koenemann S, Schubar CD (eds.). Phylogeography and Population Genetics in Crustacea, 1 st edn. CRC Press, Boca Raton, FL.

Berry TE, Saunders BJ, Coghlan ML, Stat M, Jarman S, Richardson AJ, Davies CH, Berry O, Harvey ES, Bunce M. 2019. Marine environmental DNA biomonitoring reveals seasonal patterns in biodiversity and identifies ecosystem responses to anomalous climatic events. PLoS Genet 15: 1-19. DOI: 110.1371/ journal.pgen.1007943.

Best MB, Hoeksema BW, Moka W, Moll H, Suharsono, Sutarna IN 1989. Recent scleractinian coral species collected during the SnelliusII expedition in Eastern Indonesia. Netherlands J Sea Res 23: $107-$ 115. DOI: 10.1016/0077-7579(89)90005-7.

Bourlat SJ, Borja A, Gilbert J, Taylor MI, Davies N, Weisberg SB, Griffith JF, Lettieri T, Field D, Benzie J, Glöckner FO, Rodríguez-Ezpeleta N, Faith DP, Bean TP, Obst M.2013. Genomics in marine monitoring: New opportunities for assessing marine health status. Mar Pollut Bull 74: 19-31. DOI: 10.1016/j.marpolbul.2013.05.042.

Bowen BW, Yasuda N, Malay MCMD, von der Heyden S, Paulay G, Rocha LA, Selkoe KA, Barber PH, Williams ST, Lessios HA, Crandall ED, Bernardi G, Meyer CP, Carpenter KE, Toonen RJ. 2014. Phylogeography unplugged: comparative surveys in the genomic era. Bull Mar Sci 90 (1): 13-46. DOI: 10.5343/bms.2013.1007

Burke L, Reytar K, Spalding M, Perry A. 2012. Reefs at Risk Revisited in the Coral Triangle. World Resources Institute, Washington DC.

Cabral RB, Geronimo RC. 2018. How important are coral reefs to food security in the Philippines? Diving deeper than national aggregates and averages. Mar Policy 91: 136-141. DOI 10.1016/j.marpol.2018.02.007.

Crandall ED, Riginos C, Bird CE, Liggins L, Treml E, Beger M, Barber PH, Connolly SR, Cowman PF, DiBattista JD, Eble JA, Magnuson SF, Horne JB, Kochzius M, Lessios HA, Liu SYV, Ludt WB, Madduppa H, Pandolfi JM, Toonen RJ, Gaither MR. 2019. The molecular biogeography of the Indo-Pacific: Testing hypotheses with multispecies genetic patterns. Glob Ecol Biogeogr 28: 943-960. DOI: $10.1111 /$ geb. 12905 .

CRITC. 2012. Ekositem Pesisir Perairan Pangkajene Kepulauan dan Sekitarnya Propinsi Sulawesi Selatan. CRITC-Puslit Oseanografi LIPI, Jakarta. [Indonesian]

Cullen LC. 2010. Marine resource dependence and natural resource use patterns in the Wakatobi. In: Clifton J, Unsworth RRK, Smith DJ (eds). Marine Research and Conservation in the Coral Triangle. Nova Science Publishers, Inc., New York.

Decarlo TM, Cohen AL, Wong GTF, Davis KA, Lohmann P, Soong K 2017. Mass coral mortality under local amplification of $2^{\circ} \mathrm{C}$ ocean warming. Nat Publ Gr 7: 44586. DOI: 10.1038/srep44586.

Edinger EN, Jompa J, Limmon G V, Widjatmoko W, Risk MJ. 1998. Reef degradation and coral biodiversity in Indonesia: Effects of land-based pollution, destructive fishing practices and changes over time. Mar Pollut Bull 36: 617-630. DOI: 10.1016/S0025-326X(98)00047-2.

Ferse S, Knittweis L, Krause G, Maddusila A, Glaser M. 2012 Livelihoods of ornamental coral fishermen in South Sulawesi/Indonesia: Implications for management. Coast Manag 40: 525-555. DOI: 10.1080/08920753.2012.694801

Ferse SCA, Glaser M, Neil M, Máñez SK. 2014. To cope or to sustain? Eroding long-term sustainability in an Indonesian coral reef fishery. Reg Environ Chang 14: 2053-2065. DOI: 10.1007/s10113-012-03421

Gittenberger A, Reijnen BT, Hoeksema BW. 2011. A molecularly based phylogeny reconstruction of mushroom corals (Scleractinia: Fungiidae) with taxonomic consequences and evolutionary implications for life history traits. Contrib Zool 80 (2): 107-132. DOI: 10.1163/18759866-08002002.

Glaser M, Plass-Johnson JG, Ferse SCA, Neil M, Satari DY, Teichberg M, Reuter H. 2018. Breaking resilience for a Sustainable Future: Thoughts for the Anthropocene. Front Mar Sci 5: 1-7. DOI: 10.3389/fmars.2018.00034

Green AL, Fernandes L, Almany G, Abesamis RA, Mcleod E, Alino PM, White AT, Salm R, Tanzer JM, Pressey RL. 2014. Designing marine reserves for fisheries management, biodiversity conservation, and climate change adaptation. Coast Manag 42: 37-41. DOI: 10.1080/08920753.2014.877763.

Heery EC, Hoeksema BW, Browne NK, Reimer JD, Ang PO, Huang D, Friess DA, Chou LM, Loke LHL, Saksena-Taylor P, Alsagoff N,
Yeemin T, Sutthacheep M, Vo ST, Bos AR, Gumanao GS, Hussein SMA, Waheed Z, Lane DJW, Johan O, Kunzmann A, Jompa J, Suharsono, Taira D, Bauman AG, Todd PA. 2018. Urban coral reefs: Degradation and resilience of hard coral assemblages in coastal cities of East and Southeast Asia. Mar Pollut Bull 135: 654-681. DOI: 10.1016/j.marpolbul.2018.07.041

Hoegh-guldberg O, Kennedy E V, Beyer HL, McClennen C, Possingham HP. 2018. Securing a long-term future for coral reefs. Trends Ecol Evol 33: 936-944. DOI: 10.1016/j.tree.2018.09.006.

Hoeksema BW. 2012a. Evolutionary trends in onshore-offshore distribution patterns of mushroom coral species (Scleractinia: Fungiidae). Contrib Zool 81: 199-221. DOI: 10.1163/1875986608104002 .

Hoeksema BW. 2012b. Distribution patterns of mushroom corals (Scleractinia: Fungiidae) across the Spermonde Shelf, South Sulawesi. Raffles Bull Zool 60 (1): 183-212.

Hoey AS, Howells E, Johansen JL, Hobbs JPA, Messmer V, McCowan D, Wilson SK, Pratchett MS. 2016. Recent advances in understanding the effects of climate change on coral reefs. Diversity 8 (2): 1-22. DOI: $10.3390 / \mathrm{d} 8020012$.

Hughes TP, Bellwood DR, Connolly SR, Cornell HV, Karlson RH. 2014. Double jeopardy and global extinction risk in corals and reef fishes. Curr Biol 24: 1-6. DOI: 10.1016/j.cub.2014.10.037.

Humanes A, Fink A, Willis BL, Fabricius KE, de Beer D, Negri AP. 2017. Effects of suspended sediments and nutrient enrichment on juvenile corals. Mar Pollut Bull 125 (1-2): 166-175. DOI: 10.1016/j.marpolbul.2017.08.003

Jompa J, Umar W, Yusuf S, Tassakka ACM, Limmon GV, Rahmi, Putri AP, Halwi, Tamti H, Moore AM. 2020. Genetic patterns of the corals Euphyllia glabrescens and Lobophyllia corymbosa across the Indonesian Archipelago. Biodiversitas 21 (6): 2492-2499. DOI: $10.13057 /$ biodiv/d210621

Kementerian Lingkungan Hidup. 2001. Keputusan Menteri Negara Lingkungan Hidup Nomor 04 Tahun 2011 tentang Kriteris Baku Kerusakan Terumbu Karang. Kementerian Lingkungan Hidup, Jakarta. [Indonesia]

Krebs CJ. 1999. Ecological Methodology. 2nd ed. Addison-Wesley Educational Publishers, Inc., Boston.

Kondo M, Hashimoto S. 2010. Coral reef biodiversity. In: McIntyre AD (eds). Life in the World's Oceans: Diversity, Distribution, and Abundance. Blackwell Publishing Ltd, USA

Kutti T, Johnsen IA, Skaar KS, Ray JL, Husa V, Dahlgren TG. 2020. Quantification of eDNA to map the distribution of cold-water coral reefs. Front Mar Sci 7: 1-12. DOI: 10.3389/fmars.2020.00446

Lloyd D, Wimpenny J, Venables A. 2010. Alfred Russel Wallace deserves better. J Biosci 35: 339-349. DOI: 10.1007/s12038-010-0039-x.

Lohman DJ, de Bruyn M, Page T, von Rintelen K, Hall R, Ng PKL, Shih H, Carvalho GR, von Rintelen T. 2011. Biogeography of the IndoAustralian Archipelago. Ann Rev Ecol Evol Syst 42: 205-226. DOI: 10.1146/annurev-ecolsys-102710-145001

Moeller M, Nietzer S, Schils T, Schupp PJ. 2017. Low sediment loads affect survival of coral recruits: The first weeks are crucial. Coral Reefs 36: 39-49. DOI: 10.1007/s00338-016-1513-1.

Moll H. 1983. Zonation and Diversity of Scleractinia on Reefs Off S. W. Sulawesi, Indonesia. Leiden University, Netherlands

Moore AM, Ndobe S, Jompa J. 2017. Fingerprints of the Anthropocene: the 2016 Coral Bleaching Event in an Equatorial Archipelago. In: Proceedings of the 4th International Marine and Fisheries Symposium 2017. Hasanuddin University, Makassar, 19-20 May 2017.

Moore AM, Ndobe S, Yasir I, Ambo-Rappe R, Jompa J. 2019. Banggai cardinalfish and its microhabitats in a warming world: A preliminary study. IOP Conf Ser Earth Environ Sci 253: 012021. DOI: 10.1088/1755-1315/253/1/012021

Morris EK, Caruso T, Buscot F, Fischer M, Hancock C, Maier TS, Meiners T, Müller C, Obermaier E, Prati D, Socher SA, Sonnemann I, Wäschke N, Wubet T, Wurst S, Rillig MC. 2014. Choosing and using diversity indices: Insights for ecological applications from the German Biodiversity Exploratories. Ecol Evol 4 (18): 3514-3524. DOI: $10.1002 /$ ece3.1155.

Muslihuddin, Salanggon AI, Ndobe S, Moore A, Ederyan. 2012. Monitoring fish home restoration modules in Central Sulawesi. Mitra Bahari 6 (1): 36-52.

Obura D. 2012. The diversity and biogeography of western Indian ocean reef-building corals. PloS ONE 7: e45013. DOI: 10.1371/journal.pone.0045013. 
Oliver ECJ, Burrows MT, Donat MG, Gupta AS, Alexander LV, PerkinsKirkpatrick SE, Benthuysen JA, Hobday AJ, Holbrook NJ, Moore PJ Thomsen MS, Wernberg T, Smale DA. 2019. Projected marine heatwaves in the 21 st century and the potential for ecological impact. Front Mar Sci 6: 00734. DOI: 10.3389/fmars.2019.00734.

Plass-Johnson JG, Bednarz VN, Hill JM, Jompa J, Ferse SCA, Teichberg M. 2018a. Contrasting responses in the niches of two coral reef herbivores along a gradient of habitat disturbance in the Spermonde Islands, Indonesia. Front Mar Sci 5: 00032. DOI 10.3389/fmars.2018.00032

Plass-Johnson JG, Schwieder H, Heiden J, Weiand L, Wild C, Jompa J, Sebastian B, Ferse SCA, Teichberg M. 2015. A recent outbreak of crown-of-thorns starfish (Acanthaster planci) in the Spermonde Islands, Indonesia. Reg Environ Chang 15 (6): 1157-1162. DOI: 10.1007/s10113-015-0821-2.

Plass-Johnson JG, Teichberg M, Bednarz VN, Gardes AA, Heiden JP, Lukman M, Minarro S, Kegler H, Weiand L, Wild C, Reuter H, Ferse SCA. 2018b. Spatio-temporal patterns in the coral reef communities of the Spermonde Islands, 2012-2014, II: Fish assemblages display structured variation related to benthic conditions. Front Mar Sci 5: 1 15. DOI: $10.3389 /$ fmars.2018.00036.

Rhyne AL, Tlusty MF, Kaufman L. 2014. Is sustainable exploitation of coral reefs possible? A view from the standpoint of the marine aquarium trade. Curr Opin Environ Sustain 7: 101-107. DOI: 10.1016/j.cosust.2013.12.001.

Sawall Y, Jompa J, Litaay M, Maddusila A, Richter C. 2013. Cora recruitment and potential recovery of eutrophied and blast fishing impacted reefs in Spermonde Islands, Indonesia. Mar Pollut Bull 74 (1): 374-382. DOI: 10.1016/j.marpolbul.2013.06.022

Strahl J, Rocker MM, Fabricius KE. 2019. Contrasting responses of the coral Acropora tenuis to moderate and strong light limitation in coastal waters. Mar Environ Res 147: 80-89. DOI: 10.1016/j.marenvres.2019.04.003.

Susanto HA, Suraji, Tokeshi M. 2015. Management of coral reef ecosystems in Indonesia: Past, present, and the future. Coast Ecosys 2: $21-41$.

Teichberg M, Wild C, Bednarz VN, Kegler HF, Lukman M, Gardes AA, Heiden JP, Weiand L, Abu N, Nasir A, Minarro S, Ferse SCA, Reuter H, Plass-Johnson JG. 2018. Spatio-temporal patterns in coral reef communities of the Spermonde Islands, 2012-2014, I: Comprehensive reef monitoring of water and benthic indicators reflect changes in reef health. Front Mar Sci 5: 1-18. DOI: 10.3389/fmars.2018.00033.

Umar W, Tassakka ACMAR, Jompa J. 2019. High genetic connectivity in a scleractinian coral (Lobophyllia corymbosa) around Sulawesi,
Indonesia. Biodiversitas 20 (12): 3484-3492. DOI: 10.13057/biodiv/d201204.

Veron J, Stafford-Smith M, DeVantier L, Turak E. 2015. Overview of distribution patterns of zooxanthellate Scleractinia. Front Mar Sci 2: 1-19. DOI: $10.3389 /$ fmars.2014.00081.

Veron JEN. 2000. Corals of the World. Australian Institute of Marine Science, Townsville, Australia.

Veron JEN, Devantier LM, Turak E, Green A, Kininmonth S, StaffordSmith M, Peterson N. 2009. Delineating the Coral Triangle. Galaxea J Coral Reef Stud 11 (2): 91-100. DOI: 10.3755/galaxea.11.91

von der Heyden S, Beger M, Toonen RJ, van Herwerden L, Juinio-Menez MA, Ravago-Gotanco R, Fauvelot C, Bernardi G. 2014. The application of genetics to marine management and conservation: Examples from the Indo-Pacific. Bull Mar Sci 90 (1): 123-158. DOI: 10.5343/bms.2012.1079.

Wallace CC. 1999. Staghorn Corals of the World: A Revision of the Genus Acropora. CSIRO Publishing, Clayton.

Wallace CC, Done BJ, Muir PR. 2012. Revision and catalogue of worldwide staghorn corals Acropora and Isopora (Scleractinia: Acroporidae) in the Museum of Tropical Queensland. Mem Queensl Museum 57 (1): 1-255.

Wallace CC, Pandolfi JM, Young A, Wolstenholme J. 1991. Indo-pacific coral biogeography: A case study from the Acropora selago group. Aust Syst Bot 4: 199-210. DOI: 10.1071/SB9910199.

Weijerman M, Veazey L, Yee S, Vache K, Delevaux JMS, Donovan MK, Falinski K, Lecky J, Oleson KL. 2018. Managing local stressors for coral reef condition and ecosystem services delivery under climate scenarios. Front Mar Sci 9: 1-16. DOI: 10.3389/fmars.2018.00425.

Williams SL, Sur C, Janetski N, Hollarsmith JA, Rapi S, Barron L, Heatwole SJ, Yusuf AM, Yusuf S, Jompa J, Mars F. 2019. Largescale coral reef rehabilitation after blast fishing in Indonesia. Restor Ecol 27: 447-456. DOI: 10.1111/rec.12866.

Yentsch CS, Yentsch CM, Cullen JJ, Lapointe B, Phinney DA, Yentsch SW. 2002. Sunlight and water transparency: Cornerstones in coral research. J Exp Mar Bio Ecol 268: 171-183. DOI: 10.1016/S00220981(01)00379-3

Yusuf S, Jompa J. 2012. First Quantitative Assessment of Coral Bleaching on Indonesian Reefs. Proceedings of the 12th International Coral Reef Symposium. Cairns, Australia, 9-13 July 2012.

Yusuf S, Zamani NP, Jompa J, Junior MZ. 2019. Larvae of the coral Acropora tenuis (Dana 1846) settle under controlled light intensity. IOP Conf Ser Earth Environ Sci 253: 012023. DOI: 10.1088/1755$1315 / 253 / 1 / 012023$ 